\title{
ENDOSCOPIC AND HISTOPATHOLOGIC GASTRIC CHANGES IN CHRONIC USERS OF PROTON-PUMP INHIBITORS
}

\author{
Sílvia Maria Perrone CAMILO'1, Élia Cláudia de Souza ALMEIDA', \\ Benito André Silveira MIRANZI ${ }^{2}$, Juliano Carvalho SILVA'1, Rosemary Simões NOMELINI ${ }^{1}$ \\ and Renata Margarida ETCHEBEHERE ${ }^{1}$
}

\begin{abstract}
Background - Proton-pump inhibitors have been used for at least two decades. They are among the most commonly sold drugs in the world. However, some controversy remains about the indications for their use and the consequences of their prolonged use. Objectives - To evaluate and compare the endoscopic and histopathologic gastric changes in chronic users of proton-pump inhibitors to changes in non-users. Methods - A prospective study performed at a tertiary Public Hospital involving 105 patients undergoing upper-gastrointestinal endoscopy. Subjects included 81 proton-pump inhibitor users and 24 non-users (control group). Biopsies of the antral-type mucosa, the antral-fundic transition, and the fundus were evaluated by the Sydney System. The presence of erosion or ulceration, lymphatic follicles, reactive gastropathy, and polypoid or epithelial hyperplasia was also determined. Serum levels of gastrin were measured. Results - We found two polyps, one in each group, both of which were negative for Helicobacter pylori. There were two cases of parietal cell hyperplasia in users of proton-pump inhibitors. Gastrin was elevated in 28 users of proton-pump inhibitors and in four members of the control group. We did not find statistically significant differences in the endoscopic or histopathologic findings between the two groups. Conclusion-Chronic use of proton-pump inhibitors for the duration examined was not associated with significant gastric changes. An interesting finding was that the 4 chronic users of proton-pump inhibitors who had serum gastrin levels above $500 \mathrm{pg} / \mathrm{mL}$ also had positive serology for Chagas disease.
\end{abstract}

HEADINGS - Gastrointestinal endoscopy. Proton-pump inhibitors. Gastrin. Chagas disease. Gastritis. Helicobacter pylori.

\section{INTRODUCTION}

Proton-pump inhibitors (PPIs) are highly effective drugs that have revolutionized the treatment of peptic acid disorders over the last two decades ${ }^{(20)}$. Omeprazole was first introduced for clinical use as a PPI in $1988^{(6,11)}$.

Most patients who use PPIs do not have a medical indication for them, generating concerns about inappropriate use. PPIs frequently are used beyond the term of their short-term indication because of a belief that they provide benefits without causing harm and because of aggressive publicity directed at patients and doctors. The availability of PPIs as over-the-counter and generic medications, as well as their long time on the market, have contributed to their increased use ${ }^{(21)}$.

Evidence for associations between PPI use and side effects has increased, although PPIs remain effective when properly indicated. More research is needed to understand the consequences of excessive use ${ }^{(20,21)}$.
There is no consensus about how to define chronic PPI use; whereas most professionals consider "chronic use" to be more than 12 continuous months, others propose a period ranging from 4 to 12 months $^{(20)}$. Menegassi et al. related PPI use to proliferative changes in the mucosa of the fundus and the gastric body, but the treatment time necessary to provoke such changes was not determined. Parietal cell hyperplasia, protrusion of the parietal cells in the lumen to the oxyntic glands, and cystic gland formation were among the described microscopic changes. The most common macroscopic change was the formation of sporadic fundic polyps that, rarely, were dysplastic ${ }^{(15)}$.

The literature describes a relationship between the duration of PPI use and the risk of polyps, especially when PPIs are used for more than 12 months. Most PPI users with fundic gland polyps (FGPs) test negative for the bacteria Helicobacter pylori (HP). Regression of FGPs after HP infection has been reported in chronic PPI users, with the appearance of

Declared conflict of interest of all authors: none

Disclosure of funding: no funding received

Universidade Federal do Triângulo Mineiro - UFTM: 2 Universidade de Uberaba - UNIUBE Uberaba, MG, Brasil.

Research performed at: Serviço de Patologia Cirúrgica e Serviço de Endoscopia Digestiva, Hospital de Clínica, Universidade Federal do Triângulo Mineiro - UFTM, Uberaba, MG, Brasil.

Correspondence: Prof. Renata Margarida Etchebehere. Serviço de Patologia Cirúrgica, UFTM. Rua Getúlio Guaritá, 130, Bairro Abadia. CEP: $38025-440$ - Uberaba, MG Brasil. E-mail: renataetch@hotmail.com 
gastritis in the gastric body, indicating the inhibitory action of HP infection on polyp development ${ }^{(11,26)}$. Reinforcing this impression, HP infection is less prevalent in patients with FGPs ${ }^{(26)}$. Despite arguments in favor of long-term PPI treatment that include claims that PPIs do not accelerate or promote gastric atrophy in the presence of HP infection, some authors have defended the strategy of treating HP infection before starting long-term treatment with PPIs or for patients already in treatment ${ }^{(20)}$.

Some controversy remains about the consequences of chronic PPI use. Therefore, we studied the endoscopic and histopathologic gastric changes arising from such use.

\section{METHODS}

This prospective study was performed on 105 patients who were treated at the outpatient clinics of various specialties at a tertiary public hospital. All patients underwent an upper-gastrointestinal endoscopy (UGIE) between May 2012 and June 2013. Among the 105 patients, 81 were chronic PPI users (PPI group) and 24 were non-users (control group). We defined chronic use of PPIs as continuous use for longer than 6 months $^{(20)}$. The Research Ethics Committee approved this study (no. 2182 of 2012).

Our main inclusion critery was the chronic use of PPIs. In the control group, were excluded only those who used PPIs irregularly and those who had prior gastric surgery, independent of other gastric complaints that led to the indication of the UGIE.

After being given clarification about the purpose of the study, patients who agreed to participate signed an informed consent form. Before the UGIE was performed, they answered a questionnaire with clinical and demographic information, including age, sex, whether they used PPIs, duration of PPI use, and PPI dosage. Patients who did not respond to the questionnaire was excluded from the study.

All patients had an indication for UGIE to be performed. We performed the procedure using the Olympus (GIF-Q150 and GIF-2T160) videogastroscopic device with an Exera-CLV-160 processor. Before performing the UGIEs, we collected $4 \mathrm{~mL}$ of blood to determine gastrin levels by chemiluminescence. Gastrin levels are reported in $\mathrm{pg} / \mathrm{mL}$. The normal reference range for gastrin is $13-115 \mathrm{pg} / \mathrm{mL}$. All patients with increasead leves of gastrin and in use of PPIs were instructed to discontinue use and their levels were remeasured after 2 weeks ${ }^{(22)}$. Among non users of PPI, other causes of mild hypergastrinemia were evaluated. All who had persistent increase of more than $500 \mathrm{pg} / \mathrm{mL}$, levels suspected for gastrinoma, were referred for further investigation ${ }^{(22)}$.

Where indicated by the endoscopist, we collected biopsies of the mucosa from areas of the antrum, incisura angularis, and gastric body. We immediately fixed the biopsies in $4 \%$ buffered formaldehyde, processed them, embedded them in paraffin, and submitted them to microtomy. Slides stained with hematoxilin-eosin were made for general evaluation. Warthin-Starry staining was used to identify bacteria that were morphologically compatible with $\mathrm{HP}^{(19)}$.
To quantify the main histopathologic changes found, we used the criteria suggested by the Sydney System ${ }^{(7,8)}$ : chronic inflammation, inflammatory activity, intestinal metaplasia, glandular atrophy, and HP quantity. We categorized the variables as "absent" or "present". When applicable, we graded them as "slight", "moderate," or "intense" $(7,8)$. We tried to evaluate the presence of erosion or ulceration, scarring, lymphatic follicles, reactive gastropathy, and epithelial or polypoid hyperplasia.

We classified the biopsies obtained from the different areas of the stomach according to the type of mucosa, as "antral", "antrum-fundic transition" (AFT), and "fundic". AFT-type mucosa is most commonly found in the area called the angular incisure of the stomach. The fundic type is found in its body of the stomach $^{(19)}$. A single medical pathologist evaluated all of the biopsies.

The obtained results were entered into a database for statistical analysis via Microsoft Access $2000^{\circledR}$. BIOSTAT ${ }^{\circledR}$ (version 5.0) was used to perform the statistical calculations. We applied Fisher's exact, the partitioning $X^{2}$, and Mann-Whitney tests. The tests were considered significant when the probability of rejecting the null hypothesis was less than $5 \%(P<0.05)$.

\section{RESULTS}

Of the 81 chronic PPI users, $97.5 \%$ used omeprazole. Of the omeprazole users, $67.1 \%$ used a dose of $20 \mathrm{mg} /$ day, $29.1 \%$ a dose of $40 \mathrm{mg} /$ day, and $3.8 \%$ a dose of $60 \mathrm{mg} /$ day. The remaining $2.5 \%$ used pantoprazole at a dose of $40 \mathrm{mg} /$ day. No one reported using other types of PPIs. Most patients $(88.9 \%)$ used PPIs for more than 12 months.

Table 1 summarizes the demographic characteristics and gastrin levels of the sample. Women predominated both groups and were the only patients to have gastrin levels above $115 \mathrm{pg} / \mathrm{mL}$. Four patients in the control group had elevated gastrin values of $154,169,282$, and $967 \mathrm{pg} / \mathrm{mL}$, respectively. One of them had positive serologies for Chagas' disease and four HP infection. Only one had serum gastrin higher than $500 \mathrm{pg} / \mathrm{mL}$ and was referred for further investigation ${ }^{(22)}$.

TABLE 1. Age, sex, race, and serum gastrin levels in patients who were chronic users of proton-pump inhibitors (PPIs) and controls. Both groups underwent upper-gastrointestinal endoscopy between May 2012 and June 2013

\begin{tabular}{lcc}
\hline Characteristics & $\begin{array}{c}\text { Controls } \\
(\mathrm{n}=24)\end{array}$ & $\begin{array}{c}\text { Chronic PPI users } \\
(\mathrm{n}=\mathbf{8 1})\end{array}$ \\
\hline Age (years) & $45.9(17-72)$ & $55.9(23-79)$ \\
Sex & $70.8 \%$ women & $83.9 \%$ women \\
& $29.2 \%$ men & $16.0 \%$ men \\
White & $66.7 \%$ & $76.5 \%$ \\
Non-white & $33.3 \%$ & $23.5 \%$ \\
Elevated gastrin* & $16.7 \%$ & $34.6 \%$ \\
\hline
\end{tabular}

Source: Data collected by the authors (2012-2013). *Serum gastrin level $>115 \mathrm{pg} / \mathrm{mL}$. 
Among chronic PPI users, 34.6\% had increased gastrin levels, ranging 119-1080 pg/mL. Stopping using the PPI was recommended and their levels were remeasured after 2 weeks ${ }^{(22)}$. Most of them showed normal levels of serum gastrin. Only four remained with hypergastrinemia, being referred for investigation, all with positive serology for Chagas disease. Only one patient persisted with levels of gastrin higher than $500 \mathrm{pg} / \mathrm{mL}$ and was referred for investigation of other causes of hypergastrinemia ${ }^{(22)}$.

Table 2 shows the macroscopic findings of the UGIEs in the two patient groups, which did not reveal statistically significant differences between the groups. The UGIEs were considered normal in $50 \%$ of the controls and $30.9 \%$ of the chronic PPI users. Despite the identification of polyps on the UGIEs in two chronic PPI users, either the polyps were not confirmed histologically or representative samples of these polyps were not collected. An FGP was confirmed in only one lesion, described as submucosal, in the chronic PPI group. This patient had been taking omeprazole for more than 12 months, had an increased gastrin level $(578 \mathrm{pg} / \mathrm{mL})$, and was HP negative. One polyp was confirmed in the control group, in a patient who had a normal gastrin level and was HP negative.

We collected antral-type gastric mucosa samples from $70.8 \%$ of patients in the control group and $76.5 \%$ of patients in the PPI group (Table 3). Glandular body atrophy in the antral mucosa was classified as "slight" in all cases from the control group. It was classified as "slight" in 76.5\% (Figure 1A), "moderate" in $17.6 \%$, and "severe" in $5.9 \%$ of atrophy cases from the PPI group $(P>0.05)$. We collected AFT-type mucosa samples from $66.7 \%$ of patients in the control group

TABLE 2. Macroscopic findings of the upper-gastrointestinal endoscopies for chronic users of proton-pump inhibitors (PPIs) and the control group. Both groups underwent upper-gastrointestinal endoscopy between May 2012 and June 2013

\begin{tabular}{lcc}
\hline Endoscopic findings & $\begin{array}{c}\text { Controls } \% \\
(\mathrm{n}=24)\end{array}$ & $\begin{array}{c}\text { Chronic PPI users \% } \\
(\mathrm{n}=81)\end{array}$ \\
\hline Antral gastritis & 33.3 & 51.8 \\
Gastritis in the body & 4.2 & 1.2 \\
Atrophic gastritis & 8.3 & 6.2 \\
Submucosal lesion & 4.2 & 2.5 \\
Gastric stasis & 0 & 2.5 \\
Pangastritis & 4.2 & 7.4 \\
Paresis & 0 & 1.2 \\
Polyps & 4.2 & 2.5 \\
Intestinal metaplasia & 0 & 1.2 \\
Ulcer & 0 & 4.9 \\
Scarring & 0 & 3.7 \\
\hline
\end{tabular}

Source: Data collected by the authors (2012-2013); Fisher's exact test and $55.6 \%$ of patients in the PPI group (Table 4). Glandular body atrophy in the AFT mucosa was classified as "slight" in all cases in both groups $(P>0.05)$. Samples of fundic-type gastric mucosa were obtained from $95.8 \%$ of patients in the control group and $95 \%$ of patients in the PPI group (Table 5). Glandular body atrophy in the fundic mucosa was classified as "slight" among all PPI users.

TABLE 3. Histopathologic findings in the antral-type gastric mucosa for patients who were chronic users of proton-pump inhibitors (PPIs) and for the control group. Biopsies were performed between May 2012 and June 2013

\begin{tabular}{lcc}
\hline Histopathologic findings & $\begin{array}{c}\text { Controls \% } \\
(\mathbf{n}=17)\end{array}$ & $\begin{array}{c}\text { Chronic PPI users \% } \\
(\mathbf{n}=62)\end{array}$ \\
\hline Erosion & 0 & 0 \\
Scarring & 5.9 & 8.1 \\
Lymphatic follicle & 35.3 & 17.7 \\
Chronic inflammation* & 88.2 & 83.9 \\
Inflammatory activity* & 35.3 & 41.9 \\
Atrophy of glandular bodies & 17.6 & 27.4 \\
Intestinal metaplasia & 17.6 & 27.4 \\
Reactive gastropathy & 0 & 0 \\
Helicobacter pylori & 41.2 & 33.9 \\
Epithelial hyperplasia & 0 & 4.8 \\
Polyps & 0 & 0 \\
\hline
\end{tabular}

Source: Data collected by the authors (2012-2013); Fisher's exact test except to chronic inflammation and inflammatory activity (Mann-Whitney test).

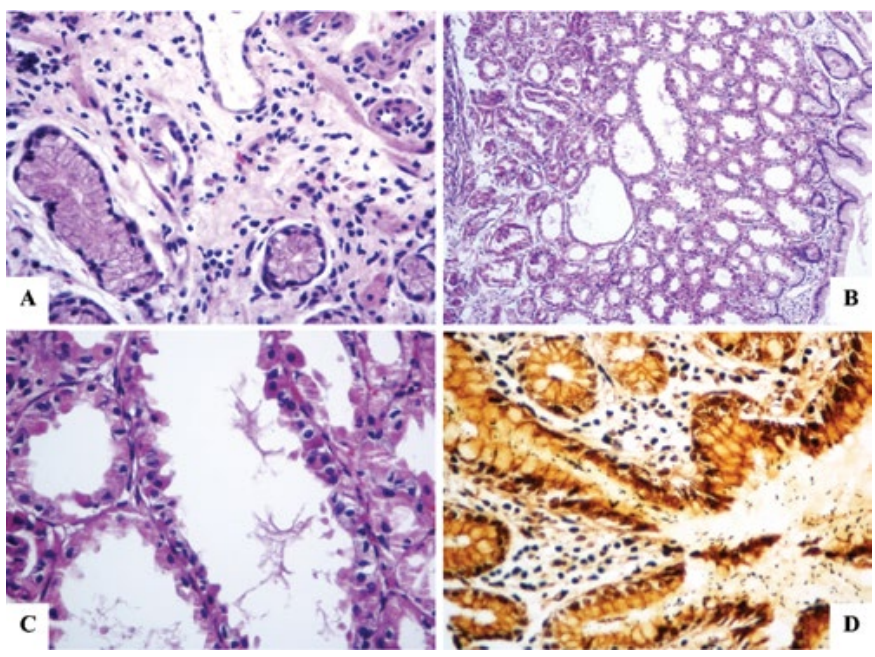

FIGURE 1. Histology slide of the antral-type gastric mucosa with slight atrophy (A), characterized by a reduction in the number of gland bodies in PPI user. (B) Fundic glands of a proton-pump user. A polyp of the fundic glands can be observed in panoramic view, highlighting the dilation of the crypts. (C) Magnification of the fundic gland polyp, showing the dilated crypt covered by fundic-type mucosa. (D) Numerous spiraled bacteria (black) are present on the surface of the epithelium and in the interior of the crypt in PPI user. (A and C - Hematoxylin-eosin, 400×; B - Hematoxylin-eosin, 100×, D - Wartin-Starry, 400×). 
TABLE 4. Histopathologic findings in the antral-fundus transition (AFT)-type mucosa for chronic users of proton-pump inhibitors (PPIs) and for the control group. Biopsies were performed between May 2012 and June 2013

\begin{tabular}{lcc}
\hline Histopathologic findings & $\begin{array}{c}\text { Controls \% } \\
(\mathbf{n}=16)\end{array}$ & $\begin{array}{c}\text { Chronic PPI users \% } \\
(\mathbf{n}=45)\end{array}$ \\
\hline Erosion & 0 & 0 \\
Scarring & 6.2 & 4.4 \\
Lymphatic follicle & 43.7 & 17.8 \\
Chronic inflammation* & 93.7 & 86.7 \\
Inflammatory activity* & 37.5 & 35.5 \\
Atrophy of glandular bodies & 12.5 & 17.8 \\
Intestinal metaplasia & 6.2 & 8.9 \\
Reactive gastropathy & 0 & 0 \\
Helicobacter pylori & 31.2 & 37.8 \\
Epithelial hyperplasia & 0 & 0 \\
Polyps & 0 & 0 \\
\hline
\end{tabular}

Source: Data collected by the authors (2012-2013); Fisher's exact test except to chronic inflammation and inflammatory activity (Mann-Whitney test)

TABLE 5. Histopathologic findings in the fundic-type mucosa for chronic users of proton-pump inhibitors (PPIs) and for the control group. Biopsies were performed between May 2012 and June 2013

\begin{tabular}{lcc}
\hline Histopathologic findings & $\begin{array}{c}\text { Controls \% } \\
(\mathbf{n}=23)\end{array}$ & $\begin{array}{c}\text { Chronic PPI users \% } \\
(\mathbf{n}=77)\end{array}$ \\
\hline Erosion & 0 & 0 \\
Scarring & 0 & 2.6 \\
Lymphatic follicle & 21.7 & 18.2 \\
Chronic inflammation* & 78.3 & 72.7 \\
Inflammatory activity* & 30.4 & 36.4 \\
Atrophy of glandular bodies & 0 & 3.9 \\
Intestinal metaplasia & 0 & 2.6 \\
Reactive gastropathy & 0 & 0 \\
Helicobacter pylori & 34.8 & 40.2 \\
Epithelial hyperplasia & 0 & 2.6 \\
Polyps & 4.3 & 1.3 \\
\hline
\end{tabular}

Source: Data collected by the authors (2012-2013); Fisher's exact test except to chronic inflammation and inflammatory activity (Mann-Whitney test).

Epithelial hyperplasia was described as parietal cells and polyps in the two groups as FGPs (Figure 1B and C). There was a statistically significant difference only when we compared the absence of atrophy and HP infection (Figure 1D) in the fundic-type gastric mucosa between the control group $(P=0.0038)$ and the PPI group $(P=0.0001)$ using the partitioning $\mathrm{X}^{2}$ test. There was no statistically significant difference when we compared other histopathologic findings in the fundic-type gastric mucosa between the two groups.

We compared the histologic changes in the three types of mucosa in samples from chronic PPI users with increased serum gastrin levels. We found HP infection in 36.3\% of antral mucosa samples, $38.4 \%$ of AFT samples, and $53.6 \%$ of fundic samples $(P>0.05)$ from patients who were chronic users of PPIs and had elevated serum gastrin levels.

\section{DISCUSSION}

Peptic-acid diseases are disorders in which gastric acid and pepsin are the necessary but insufficient pathogenic factors. Although inherently caustic, they generally do not cause lesions or gastric or esophageal symptoms because of the existence of intrinsic defense mechanisms. Peptic-acid diseases can occur when these defense mechanisms are lost. Treatment and prevention strategies of these disorders primarily focus on reducing gastric acid levels. The most powerful suppressors of gastric acid secretion are PPIs ${ }^{(25)}$. Although PPIs are medically safe, various studies emphasize their indiscriminate use and the lack of an indication for chronic use. Many prescriptions are improperly given to hospitalized patients and maintained after discharge, necessitating a more appropriate definition for PPI use ${ }^{(14)}$.

In our study, the age band and the distributions by sex and skin color were similar to those described in the literature $^{(15,20)}$. As the patient's age increases, he or she is more likely to have comorbidities and to be using other medications, thus increasing the risk of side effects. Therefore, greater care must be taken with older patients. Studies about PPIs and interactions with medications emphasize that, despite their effectiveness in equivalent doses, the choice of PPI type is important, particularly in older patients ${ }^{(27)}$. Most of our patients used omeprazole, probably because this PPI has been on the market for a long time ${ }^{(11)}$, is freely distributed by Brazilian Health Units, and is inexpensive within the Brazilian Federal Government's People's Pharmacy Program ${ }^{(16)}$. Most patients in both groups were considered to be white. Although we did not obtain specific information about the ethnicity of the target population, this fact is relevant to the metabolism of PPIs. Asian people tend to metabolize PPIs more slowly than white or black people, which could influence the effectiveness or toxicity of these drugs ${ }^{(25)}$.

Hypergastrinemia can occur as a physiologic response to the PPI-induced inhibition of gastric acid ${ }^{(9,2)}$ and appears to have a trophic effect on oxyntic mucosa ${ }^{(10)}$. When treatment is suspended, this phenomenon reverses itself. In a previous report, $10 \%-30 \%$ of chronic PPI users, especially patients infected by HP or with higher gastrin levels, had hyperplasia of the enterochromaffin cells ${ }^{(9)}$. Studies of PPI safety have noted that PPI-related hypergastrinemia is not intense ${ }^{(18)}$. These findings are consistent with those of this study, except for patients who had gastrin levels above $500 \mathrm{pg} / \mathrm{mL}$ and had positive serology for Chagas disease, other cause of hypergastrinemia ${ }^{(17,24)}$. In addition, atrophic gastritis, pernicious anemia, hyperplasia of $G$ cells in the gastric antrum, vagotomy, intestinal resection, inflammatory bowel disease, Helicobacter pylori infection, hepatic or renal insufficiency, hypercalcemia, gastrinoma and other neuroendocrine tumors may increase gastrina levels ${ }^{(22)}$. In cases of gastrinoma, is expected to increase of the gastrina levels from 5 to 10 times this dosage in serum in $90 \%$ of cases. Dosages greater than $1000 \mathrm{pg} / \mathrm{mL}$ is considered to be very suspicious for gastrinoma ${ }^{(22)}$. 
Mott et al. studied Chagas patients and found hypergastrinemia under basal conditions. This finding was explained by the low levels of hydrochloric acid in the patients' gastric secretions, the hypersensitivity of their $\mathrm{G}$ cells to denervation, and their increased production of extragastric gastrin ${ }^{(17)}$. Troncon et al. demonstrated that chronic Chagas patients with reduced gastric acid levels did not have significantly increased G-cell populations in the antrum. They indicated that in Chagas disease, the increase in gastrin associated with destruction of the intrinsic innervation of the stomach should be measured by the G-cell hyperfunction rather than by hyperplasia ${ }^{(24)}$.

FGPs have been associated with an increase in gastrin levels stemming from a probable association with long-term PPI use. It has been suggested that PPI-induced FGPs are the result of damaged glandular flow, owing to the mechanical obstruction of the gland due to the hypergastrinemia-associated hyperplasia of the parietal cells. However, this phenomenon does not appear to be related to the severity of hypergastrinemia, as equivalent degrees of hypergastrinemia have been described in PPI users with and without FGPs ${ }^{(3)}$. We did not find an association between gastrin levels and FGPs, which varied in number and arose after various periods of PPI use. In previous studies, the average time for FGPs to appear ranged from as high as 5 years ${ }^{(13)}$ to as 48 months ${ }^{(1)}$. Thus, time seems to be a predictive factor. We did not find a statistically significant association between PPI use and FGPs among patients who used PPIs for 6-12 months or for more than 12 months. The absence of a group of patients who used PPIs for more than 5 years could be a reason for this lack of an association.

Since the first reports of FGPs in PPI users, this association has been controversial. Some studies suggest that long-term therapy leads to parietal cell hypertrophy, which correlates with the development of these polyps. Others consider that long-term therapy with PPIs only leads to parietal cell hypertrophy and not to polyp formation, and that FGPs are an incidental finding. These authors conclude that FGPs are not induced by PPIs and are negatively correlated to infection by $\mathrm{HP}^{(4)}$. Various studies have described an association between FGPs and absence of infection by $\mathrm{HP}^{(2,5,11,26)}$. We did not observe a statistically significant association between FGPs and the absence of HP. The HP infection rates found in the antral mucosa $(33.9 \%)$, AFT mucosa $(37.8 \%)$, and fundic mucosa $(40.2 \%)$ among chronic users of PPIs, together with the absence of a group that had used PPIs for more than 5 years, might have influenced the low levels of polyps.

The risk that FGPs will turn malignant in chronic users of PPIs is extremely low. Therefore, it is not currently recommended that these lesions be removed or that patients with FGPs be tracked by endoscopy, unless they have a family history of polyposis ${ }^{(3)}$. Although chronic PPI use is not considered a risk for gastric cancer, changes to a model of gastritis have been described from the antrum to the gastric body, particularly in people infected by HP. These changes are associated with a risk of gastric cancer ${ }^{(20,23)}$. This association between HP infection and atrophic gastritis in the gastric body of chronic PPI users has been implicated in the recommendation that HP be eradicated ${ }^{(20)}$. Raughunath, Morain, McLoughin, ${ }^{(20)}$ and Sanduleanu et al. ${ }^{(23)}$ described a greater occurrence of atrophy in the gastric body of patients infected by HP. Here, we more frequently observed glandular body atrophy in the antral mucosa of patients who were chronic PPI users, whereas HP infection was more often present in the fundic mucosa. There was a statistically significant difference only when we compared the absence of atrophy to the absence of HP infection in the fundic-type mucosa within the two groups.

The sensitivity and specificity of histology to diagnose HP infection range from $53 \%$ to $90 \%$, depending on the pathologist's experience and the density of colonization. Increasing the number of biopsies and using special coloring techniques, such as used in this study, can increase the sensitivity of the method ${ }^{(12)}$.

The slight parietal cell hyperplasia observed in chronic users of PPIs can be attributed to the trophic action of increased gastrin. This hyperplasia included increases in the size and number of cells, as well as in the salience of the apical cell membrane of the gland's lumen. The inhibition of the active secretion of the acid-filled secretor canaliculi might also partially explain the hypersecretion of reflux acid after interrupting treatment ${ }^{(5)}$. We found parietal cell hyperplasia in the fundic-type gastric mucosa of two chronic users of PPIs, one of whom had used omeprazole for more than 12 months and the other for 6-12 months. However, when we compared these findings to the control group, the difference was not statistically significant.

\section{CONCLUSION}

This study did not find an association between chronic PPI use and FGPs, parietal cell hyperplasia, HP infection, and other histopathologic or endoscopic changes. However, the absence of a group of patients who had used PPIs for more than 5 years might have influenced the results. One important finding was a positive serology for Chagas disease in four chronic PPI users who had serum gastrin levels above $500 \mathrm{pg} / \mathrm{mL}$.

\section{Author contribution}

Camilo SMP, participated in the design of the project, execution of the research and compilation of the text; ECS Almeida participated in the statistical analysis and compilation of the text; BAS Miranzi, participated in the statistical analysis; Silva JC, participated in the collection of gastrin, as well as making and staining the histological slides; Nomelini RS, participated in the data and sample collection; Etchebehere RM, participated in the design of the project, project coordination, execution of the research and compilation of the text. 
Camilo SMP, Almeida ECS, Miranzi BAS, Silva JC, Nomelini RS, Etchebehere RM. Alterações endoscópicas e histopatológicas gástricas em pacientes usuários crônicos de inibidores de bomba de prótons. Arq Gastroenterol. 2015,52(1):59-64.

DESCRITORES - Contexto - Os inibidores da bomba de prótons são usados há pelo menos duas décadas e estão entre as drogas mais vendidas no mundo. Ainda existem controvérsias sobre as indicações e as consequências de seu uso a longo prazo. Objetivos - Avaliar as alterações endoscópicas e histopatológicas gástricas em usuários crônicos de inibidores da bomba de prótons e comparar com controles. Métodos - Estudo prospectivo realizado em Hospital Público terciário com 105 pacientes, 81 usuários de bomba de prótons e 24 controles, submetidos a endoscopia digestiva alta. As biópsias das mucosas do tipo antral, da transição antro fúndica e fúndica foram avaliadas segundo a Classificação de Sidney e verificando também erosão ou úlcera, folículo linfático, gastropatia reativa, hiperplasia epitelial e pólipo. Realizada também a dosagem sérica da gastrina. Resultados Encontramos dois pólipos, um em cada grupo, ambos negativos para Helicobacter pylori e dois casos de hiperplasia de células parietais nos usuários de inibidores da bomba de prótons. A gastrina estava aumentada em 28 usuários de inibidor da bomba de protóns e em 4 do grupo controle. Não encontramos diferenças estatisticamente significantes nos achados endoscópicos e histopatológicos dos dois grupos. Conclusão - O uso crônico de inibidores da bomba de prótons no período examinado não se associou com alterações gástricas significantes. O achado mais importante foi a positividade das sorologias para doença de Chagas nos quatro pacientes do grupo de usuários crônicos de inibidores que apresentavam níveis de gastrina sérica superiores a $500 \mathrm{pg} / \mathrm{mL}$.

DESCRITORES - Endoscopia gastrointestinal. Inibidores da bomba de prótons. Gastrinas. Doença de Chagas. Gastrite. Helicobacter pylori.

\section{REFERENCES}

1. Ally MR, Veerappan GR, Maydonovitch CL, Duncan TJ, Perry JL, Osgard EM, et al. Chronic proton pump inhibitor therapy associated with increased development of fundic gland polyps. Dig Dis Sci. 2009;54(12):2617-22.

2. Alqutub AN, Masoodi I. A case of gastric polyposis in antral area of stomach following prolonged proton-pump therapy. Ger Med Sci. 2010;2:1-4.

3. Burkitt MD, Varro A, Pritchard DM. Importance of gastrin in the pathogenesis and treatment of gastric tumors. World J Gastroenterol. 2009;15(1):1-16.

4. Cao H, Qu R, Zhang Z, Kong X, Wang S, Jiang W, et al. Sporadic fundic gland polyps are not associated with proton pump inhibitors therapy but negatively correlate with helicobacter pylori infection in China. Chin Med J (Engl). 2014;127(7):1239-43.

5. Cats A, Schenk BED, Bloemena E, Roosendaal R, Lindeman J, Biemond I. et al Parietal cell protrusions and fundic gland cysts during omeprazole maintenance treatment. Hum Pathol. 2000;31(6):684-90.

6. Dias MGM, Dani R, Lima EJM. Farmacoterapia, aparelho digestivo e o paciente geriátrico. In: Dani R. Gastroenterologia essencial. 4th ed. Rio de Janeiro: Guanabara Koogan; 2011. p. 1168-78.

7. Dixon MF, Path FRC, Genta RM, Yardley JH, Correa P. Classification and grading of gastritis: the updated Sydney System. Am J Surg Pathol. 1996;20(10):1161-81.

8. Eisig JN, Ferreira RPB. Doenças do estômago e duodeno. In: Martins MA Carrilho FJ, Alves VAF, Carrilho EA, Cerri GG, Wen CL. Clínica médica: volume 4: doenças do aparelho digestivo, nutrição e doenças nutricionais. Barueri: Manole; 2009. p. 96-119.

9. Espugues JV, Marti-Cabrera, M. Seguridad e interaciones de los IBP. Gen. 2010;64(3):221-7.

10. Fossmark R, Jianu CS, Martinsen TC, Qviqstad G, Syversen U, Waldum HL. Serum gastrin and chromogranin a levels in patients with fundic gland polyps caused by long-term proton-pump inhibiton. Scand J Gastroenterol. 2008;43(1):20-4

11. Freeman HJ. Proton pump inhibitors and an emerging epidemic of gastric fundic gland polyposis. World J Gastroenterol. 2008;7(14):1318-20.

12. González EG, Perez GIP, Garza H, Padilha FJB. A review of Helicobacter pylori diagnosis, treatment, and methods to detect eradication. World J Gastroenterol. 2014;20(6):1438-49.

13. Jalving M, Koornstra JJ, Wesseling J, Boezen HM, Jong S, Kleibeuker JH Increased risk of fundic gland polyps during long-term proton pump inhibitor trerapy. Aliment Pharmacol Ther. 2006;24(9):1341-8.
14. Martín-Echevarría E, Juliá AP, Torralba M, Pereda GA, Dávila PM, Mateos J. et al. Assessing the use of proton pump inhibitors in internal medicine department. Rev Esp Enferm Dig. 2008;100(2):76-81.

15. Menegassi VS, Czeczko LEA, Czeczko LSG, Ioshii SO, Pisani JC, Ramos Jr O Prevalência de alterações proliferativas gástricas em pacientes com uso crônico de inibidores de bomba de prótons. ABCD, Arq Bras Cir Dig. 2010;23(3):145-9.

16. Ministério da Saúde (Brasil). Elenco oficial dos medicamentos disponibilizados pela rede própria do programa Farmácia Popular do Brasil. [2012]. [cited 2014 May 14]. Available from: http://portalsaude.saude.gov.br/images/pdf/2014/fevereiro/20/ elenco-fp1-20-08-12.pdf

17. Mott CB, Guarita DR, Sipahi AM, Betarello A. Hormônios Gastro-entero-pancreáticos em portadores de Doença de Chagas crônica. Rev Hosp Clin Fac Med Univ São Paulo. 1989;44(2):63-72.

18. Oscanoa Espinoza TJ. Seguridad de los inhibidores de la bomba de protones. Rev Gastroenterol Perú. 2011;31(1):49-55.

19. Owen DA. Stomach. In: Milss SE. Histology for Pathologists. 5. ed. New York: Lippincott Wiliams \& Wilkins; 2012. p. 633-46.

20. Raugnunath AS, O'Morain C, McLoughlin RC. Review article: the long-term use of próton-pump inhibitors. Aliment Pharmacol Ther. 2005;22(Suppl 1):S55-63.

21. Rotman SR, Bishop TF. Proton pump inhibitor use in the U.S. Ambulatory Setting, 2002-2009. PLoS One. 2013;8(2):1-8.

22. Sanabria C, Pérez-Ferre N, Lecumberri E, Miguel P. Gastrinoma. Endocrinología y Nutrición. 2007;54(Suppl 1):S21-30.

23. Sanduleanu S, Jonkers D, Bruine A, Hameeteman W, Stockbrügger W. Non-Helicobacter pylori bacterial flora during acid-suppressive therapy: differential findings in gastric juice and gastric mucosa. Aliment Pharmacol Ther. 2001;15(3):379-88.

24. Troncon LEA, Barbosa AJA, Romanello LMF, Toppa NH. Antral gastrin cell population in patients with chagasic megaesophagus and megacolon. Braz J Med Biol Res. 1994;27(3):645-53.

25. Wallace JL, Sharkey KA. Farmacoterapia da acidez gástrica, úlceras pépticas e doença do refluxo gastroesofágico. In: Bruton LL, Chabner BA, Knollmann BC. As bases farmacológicas da terapêutica de Goodman e Gilman. 12. ed. Porto Alegre: Artmed; 2012. p. 1309-22.

26. Watanabe N, Seno H, Nakajima T, Yazumi S, Miyamoto S, Matsumoto S. et al Regression of fundic gland polyps following acquisition of Helicobacter pylori. Gut. 2002;51(5):742-5

27. Wedmeyer RS, Blume H. Pharmacokinetic drug interaction profiles of proton pump inhibitors: an update. Drug Saf. 2014;37(4):201-11. 